\title{
HIV/AIDS patients adherence to antiretroviral therapy and the impact of the use of psychoactive substances
}

\author{
O impacto do uso de substâncias psicoativas na aderência à terapia antirretroviral de \\ pacientes HIV/AIDS
}
El impacto del uso de sustancias psicoativas en la adherencia a la terapia antirretroviral de pacientes VIH / SIDA

Lucia Helena Gonzales Real ${ }^{1 *}$, Karen Jansen², Fernanda Pedrotti Moreira ${ }^{2}$, André Gonzales Real ${ }^{3}$.

\begin{abstract}
ABSTACT
Objective: Describe the profile of the HIV/AIDS patients who use psychoactive substances; relate the use of psychoactive substances and Antiretroviral Therapy (ART) to non-adherence; and identify the main barriers for non-adherence. Methods: A cross-sectional study in a population of HIV/AIDS patients under ART prescription. Non-adherence to ART was considered when the patients presented a viral load higher than 40 copies per $\mathrm{mL}$. The use of psychoactive substances was evaluated by Alcohol, Smoking and Substance Involvement Screening Test (ASSIST). Results: From 320 HIV/AIDS patients analyzed, $18.8 \%$ were not adhering to ART, $25.8 \%$ used alcohol, $21.7 \%$ smoked and $29.7 \%$ used some illicit psychoactive substance. The barriers were: high number of pills to be taken; fear that other people may know they are sick; difficulty of taking so many pills (if they do not feel sick); and they do not believe in the efficacy of the treatment (would rather try alternative treatments). Conclusion: Patients under higher risk are not white and young, from lower social classes, and use psychoactive substances. Strategies should focus on the promotion of adherence considering the barriers reported.
\end{abstract}

Key-words: HIV/AIDS; non-adherence to ART; antiretroviral therapy; viral load; psychoactive substances.

\section{RESUMO}

Objetivo: Descrever o perfil dos pacientes com HIV/AIDS que usam substâncias psicoativas; relacionar o uso de substâncias psicoativas com a não aderência à Terapia Antirretroviral (ART); e identificar as principais barreiras para a não adesão. Métodos: Foi realizado um estudo transversal em uma população de pacientes com HIV/AIDS com prescrição de ART. Não aderência à ART foi considerada quando os pacientes apresentavam carga viral maior que 40 cópias por $\mathrm{mL}$. O uso de substâncias psicoativas foi avaliado pelo "Alcohol, Smoking and Substance Involvement Screening Test" (ASSIST). Resultados: Dos 320 pacientes analisados, 18,8\% foram considerados não-aderentes à ART, 25,8\% usavam álcool, 21,7\% eram fumantes e 29,7\% faziam uso de alguma substância psicoativa ilícita. As barreiras para adesão à TARV entre os pacientes que faziam uso de substâncias psicoativas foram: dificuldade de ingerir muitos comprimidos; estar muito atarefado; necessidade de compartilhar a TARV com familiares e/ou amigos; medo/preocupação que outras pessoas saibam da doença; não se sentir doente; achar que o tratamento não funciona e preferir tratamentos alternativos. Conclusão: pacientes com maior risco foram os não-brancos, jovens, com maior vulnerabilidade social e que faziam uso de substâncias psicoativas. Estratégias para o aumento da aderência devem ser focadas nas barreiras relatadas pelos pacientes.

Palavras-Chave: HIV/AIDS, Não adesão ART, Terapia antirretroviral, Carga viral, Substâncias psicoativas.

${ }^{1}$ Faculdade de Medicina da Universidade Federal de Pelotas (RS-Brasil). *E-mail: luciagreal@gmail.com ${ }^{2}$ Universidade Católica de Pelotas (RS-Brasil).

${ }^{3}$ Ciências Médicas: Psiquiatria, Universidade Federal do Rio Grande do Sul (RS-Brasil).

SUBMETIDO EM: 3/2019
ACEITO EM: 4/2019
PUBLICADO EM: 6/2019

REAS/EJCH | Vol. 11 (12) | e640 | DOI: https://doi.org/10.25248/reas.e640.2019 Página 1 de 10 


\section{RESUMEN}

Objetivos: Describir el perfil de los pacientes con HIV/SIDA que usan sustancias psicoactivas; relacionar el uso de sustancias psicoactivas con la no adherencia a la Terapia Antirretroviral (ART); e identificar las principales barreras para la no adhesión. Métodos: Se realizó un estudio transversal en una población de pacientes con HIV/SIDA con prescripción de ART. Fue considerada no adherencia al ART cuando los pacientes presentaban carga viral mayor que 40 copias por $\mathrm{mL}$. El uso de sustancias psicoactivas se evaluó por el "Alcohol, Smoking and Substance Involvement Screening Test" (ASSIST). Resultados: De los 320 pacientes analizados, 18,8\% fueron considerados no adherentes al ART, 25,8\% usaban alcohol, 21,7\% eran fumadores y 29,7\% consumían alguna sustancia psicoactiva ilícita. Las barreras para adhesión al TARV entre los pacientes que consumían sustancias psicoactivas fueron: dificultad para ingerir muchas pastillas, estar muy ocupado; necesidad de compartir la TARV con familiares y/o amigos; miedo/preocupación de que otras personas supieran de la enfermedad; no sentirse enfermo; creer que el tratamiento no funciona y preferir tratamientos alternativos. Conclusión: Pacientes con mayor riesgo fueron los que no son de raza blanca, jóvenes, con mayor vulnerabilidad social y que consumían sustancias psicoactivas. Estrategias para el aumento de adherencia deben ser enfocadas en las barreras relatadas por los pacientes.

Palabras clave: VIH / SIDA, No adhesión ART, Terapia antirretroviral, Carga viral, Sustancias psicoactivas.

\section{INTRODUCTION}

Data from the Joint United Nations Program on HIV/AIDS (UNAIDS), published in 2017, reported that 36.7 million people worldwide were infected by the HIV virus in 2016. In Brazil, the latest epidemiological report (Epidemiological Report - 2017, www.aids.gov.br) informed that between 1980 and 2017 882,810 new HIV cases were notified. However, after the introduction of the antirretroviral therapy there has been a significant decrease in the morbidity and mortality rates related to the HIV infection, which resulted in an increase of the life expectancy of people living with HIV/AIDS (MCNEIL R, et al. 2017; KALICHMAN SC, et al , 2016; GARRIGA C. et al., 2015; KALICHMAN SC, et al., 2014; O'NEIL CR, et al.,2012).

Antiretroviral therapy (ART) is highly associated to sustained viral suppression, as it prevents the progression of the HIV infection and its transmission (JOSEPH B., et al., 2015).

However, the success of the ART depends on high levels of adherence and studies have shown that patients should take $95 \%$ of the daily recommended doses to maintain plasma HIV viral load undetectable (MALTA M, et al., 2008; MCNEIL R, et al.; 2017; PATERSON DL, et al. 2000). Therefore, the factors that would contribute to the maintenance of undetectable viral load among patients with HIV/AIDS have been the focus of some studies (O'NEIL 2012; MCNEIL R, et al. 2017; LANGEBEEK N, et al. 2014; BEER L, SKARBINSKI J, 2014).

Different factors have been associated to the non-adherence to ART, and studies have shown that the use of psychoactive substances (licit and illicit) is a relevant predictor to non-adherence, as the patients who make use of these substances tend to interrupt the treatment and have their viral load increased (HINKIN CH, et al., 2007; HENDERSHOT CS, et al., 2009; LANGEBEEK N, et al., 2014).

Recent studies regarding the impact of the use of licit drugs, alcohol and smoking, on ART adherence have detected that the disorders caused by the alcohol have a negative impact on the adherence (AZAR MM, et al. 2010; KALICHMAN SC, et al., 2013; KALICHMAN SC, et al., 2014; NAKIMULI-MPUNGU E, et al. 2012). Furthermore, another study with HIV/AIDS patients who smoked revealed that the ones who used illicit drugs had twice the probability of non-adherence to the treatment (ARNSTEN JH, et al., 2007).

Literature regarding the relationship between the use of illicit substances and ART adherence is scarce, however the use of these substances, including injecting drugs, has been presented as a significant risk factor to the patients who are more prone to abandon the specialized health service for more than 12 months

REAS/EJCH | Vol. 11 (12) | e640 | DOI: https://doi.org/10.25248/reas.e640.2019 Página 2 de 10 
(O'CONNOR JL, et al., 2013) and, finally, abandon ART. When it happens, the use of psychoactive substances impairs even further the already fragile immunological system, decreasing the levels of T CD4 lymphocyte (LTCD4+), which are the main cells infected by the HIV. Such cells act as a receptor of the virus and mediate the HIV cell invasion, which leads to the consequent progression of the disease into AIDS and the increase of the risk of opportunistic infections (ROMEU G, et al., 2012; SILVA JAG, 2015).

Finally, the use of psychoactive substances is one of the barriers to the use of antiretrovirals, and understanding the way it affects the treatment of HIV/AIDS patients may result in effective interventions to avoid ART non-adherence (GONZALEZ A, et al., 2011).

Therefore, the aims of this study are to describe the profile of the HIV/AIDS patients who use psychoactive substances, evaluate the relationship between the use of psychoactive substances and ART non-adherence, and identify the main barriers for non-adherence in this population.

\section{METHODS}

This is a cross-sectional study performed with a population of HIV/AIDS patients to whom ART was prescribed. The patients who agreed to take part in the study were being attended in a specialized treatment center for patients with HIV/AIDS (Southern Brazil) within May 2016 and June 2017. Inclusion criteria: being 18 years old or older; and being using ART for at least one year.

Exclusion criteria: patients who were institutionalized (homeless patients, incarcerated patients or the ones who live in therapeutic clinics); being pregnant; and patients who began ART in another specialized service. This study was approved by the ethics committee of the Catholic University of Pelotas $\left(n_{\circ} 1.330 .026\right)$. Patients who agreed in taking part of the study signed an informed consent form.

Initially, the patients answered to a questionnaire about their sociodemographic characteristics: gender, age, education, marital status and economic classification (according to the Brazilian Research Association "Associação Brasileira de Empresas de Pesquisa - $A B E P$ "). This questionnaire also asked questions about the general health of the patient: age at diagnosis; how long since HIV diagnosis; how long using ART; chronic use medication (polypharmacy); and comorbidities and intercurrences associated to the HIV infection.

The Alcohol, Smoking and Substance Involvement Screening Test (ASSIST) was used to evaluate of the occurrence of disorders related to the use of psychoactive substances, the test was developed by the World Health Organization (WHO) and validated to the Brazilian population by Henrique et al. (2004). A cutoff of 4 was used to define abuse/dependence of illicit substances and one of 11 for alcohol (POBLETE F, et al., 2017). The illicit substances used were evaluated separately; however, one unique variable was latter created and called "illicit psychoactive substances".

Medical records of the patients were used to collect data about their plasma viral load, and patients were considered non-adherent when their viral load was above 40 copies per $\mathrm{mL}$ in the last six months. The plasma viral load was measured by Abbott Real time and the results given in copies of RNA/mL.

The main reasons for the non-adherence to ART were evaluated by the self-report questionnaire of the AIDS Clinical Trials Group adjusted for the Brazilian population. The questionnaire has 21 questions regarding the barriers for the non-adherence to ART among patients who did not take some doses of the medication in the last 30 days (CHESNEY MA, et al, 2000).

Data were entered twice in EpiData 3.1, checked and further corrected for the inconsistencies, and transferred to the software Stata 13. The characteristics of the patients were described either by absolute and relative frequencies or by median and interquartile ranges, depending on the classification of the variable.

The chi-square test was used to evaluate the factors associated to the disorders caused by the use of psychoactive drugs; the factors associated to the non-adherence to ART; and the difference among the barriers described by the user and the non-users of psychoactive substances. Poisson Regression was used to estimate the prevalence ratios (PR) with a confidence interval of $95 \%$ and to adjust possible confounders $(p<0.20$ in crude analysis), limits of significance were established in $p<0.05$. 


\section{RESULTS}

The total sample was comprised by 320 HIV/AIDS patients. Most patients were women (55.9\%), with white skin color $(61.4 \%)$, aged between 40 and $59(51.3 \%)$, who did not finish primary school $(55.6 \%)$ and had no spouse $(58.8 \%)$. Most patients were from middle $(47.6 \%)$ or low $(39.1 \%)$ classes (Table 1). The average time of the HIV diagnostic was of 8 years (4-13 years) and the average time of ART was of 6 years (3-10 years). Finally, $15 \%$ of the patients made use of polypharmacy, the chronic use of five or more medications and $67.2 \%$ used an ART regimen with one or more antiretroviral pills.

Table 1 - Prevalence of non-adhesion to the antiretroviral therapy and its associated social factors.

\begin{tabular}{|c|c|c|c|c|}
\hline \multirow[t]{2}{*}{ Characteristics of the sample } & \multirow{2}{*}{$\begin{array}{c}\text { Distribution in the sample } \\
n(\%)\end{array}$} & \multicolumn{3}{|c|}{ Non-adhesion to ART } \\
\hline & & n (\%) & RP (IC 95\%) & p-value \\
\hline Sex & & & & 0.241 \\
\hline Female & $179(55.9)$ & $29(16.2)$ & 1.00 & \\
\hline Male & $141(44.1)$ & $31(22.0)$ & $1.36(0.86 ; 2.14)$ & \\
\hline Colour of the skin* & & & & 0.030 \\
\hline Not-white & $123(38.6)$ & $31(25.2)$ & $1.70(1.08 ; 2.68)$ & \\
\hline White & $196(61.4)$ & $29(14.8)$ & 1.00 & \\
\hline Age (years) & & & & 0.001 \\
\hline $18-39$ & $115(35.9)$ & $34(29.6)$ & $3.03(1.14 ; 8.03)$ & \\
\hline $40-59$ & $164(51.3)$ & $22(13.4)$ & $1.37(0.50 ; 3.78)$ & \\
\hline 60 or older & $41(12.8)$ & $4(9.8)$ & 1.00 & \\
\hline Primary School & & & & 0.077 \\
\hline Not completed & $178(55.6)$ & $40(22.5)$ & $1.59(0.98 ; 2.60)$ & \\
\hline Completed & $142(44.4)$ & $20(14.1)$ & 1.00 & \\
\hline Economic classification* & & & & 0.026 \\
\hline$A+B$ & $42(13.2)$ & $2(4.8)$ & 1.00 & \\
\hline $\mathrm{C}$ & $151(47.6)$ & $30(19.9)$ & $4.17(1.04 ; 16.78)$ & \\
\hline $\mathrm{D}$ & $124(39.1)$ & $28(22.6)$ & $4.74(1.18 ; 19.10)$ & \\
\hline Marital Status & & & & 0.161 \\
\hline Single & $111(34.7)$ & $27(24.3)$ & $1.70(0.90 ; 3.22)$ & \\
\hline Married/ Has a partner & $132(41.3)$ & $22(16.7)$ & $1.17(0.60 ; 2.27)$ & \\
\hline Separated / divorced & $77(24.1)$ & $11(14.3)$ & 1.00 & \\
\hline Total & $320(100)$ & $60(18.8)$ & --- & --- \\
\hline
\end{tabular}

Subtitle: Data presented by absolute $(n)$ and relative $(\%)$ frequencies $(n)$; values of statistical significance $(p-$ value). estimated by Chi-square test; prevalence ratio (PR) and confidence intervals ( $\mathrm{Cl}$ ) calculated by Poisson Regression. * Variables with missing values.

Source: Data from this research (2016-2017).

Analyzing the total sample, we found that $54.7 \%$ matched the criteria for disorders caused by tobacco, $20.6 \%$ by alcohol, $18.4 \%$ by marijuana, $16.6 \%$ by crack and/or cocaine and $23.1 \%$ by different psychoactive illicit substances, including the ones before. The use was more prevalent among no white skin and single men $(p<0.05)$ (Table 2). 
Being young was also associated to the use of psychoactive substances $(p<0.05)$, except for alcohol consumption. Patients who did not finish primary school were more likely to present disorders by the use of tobacco $(p=0.029)$ and alcohol $(p=0.043)$, however, education was not correlated to the use of any of the illicit drugs.

Finally, the relation between economic class and the use of psychoactive substances showed that low class patients were more prone to disorders related to the use of tobacco $(p=0.032)$ and crack and/or cocaine $(p=0.029)($ Table 2$)$.

Table 2 - Prevalence and sociodemographic factors associated to the disorders caused by the use of psychoactive substances.

\begin{tabular}{|c|c|c|c|c|c|}
\hline Social demographic factors & Tobacco & Alcohol & Marijuana & $\begin{array}{l}\text { Crack/ } \\
\text { Cocaine }\end{array}$ & $\begin{array}{c}\text { Any illicit } \\
\text { psychoactive } \\
\text { substance }\end{array}$ \\
\hline & $\begin{array}{c}\text { p-valor } \\
\text { n (\%) }\end{array}$ & $\begin{array}{l}\text { p-valor } \\
\text { n (\%) }\end{array}$ & $\begin{array}{l}\text { p-valor } \\
\text { n (\%) }\end{array}$ & $\begin{array}{c}\text { p-valor } \\
\mathrm{n}(\%)\end{array}$ & $\begin{array}{c}\text { p-valor } \\
\text { n (\%) }\end{array}$ \\
\hline Sex & $p=0.025$ & $\mathrm{p}<0.001$ & $\mathrm{p}<0.001$ & $p<0.001$ & $p<0.001$ \\
\hline Female & $88(49.1)$ & $19(10.6)$ & $19(10.6)$ & $17(9.5)$ & $24(13.4)$ \\
\hline Male & $87(61.7)$ & 47 (33.3) & $40(28.4)$ & $36(25.5)$ & $50(35.4)$ \\
\hline Colour of the skin & $p=0.015$ & $p=0.015$ & $p=0.015$ & $p=0.042$ & $p=0 ., 021$ \\
\hline Not-white & $78(63.4)$ & $34(27.6)$ & $31(25.2)$ & 27 (21.9) & $37(30.1)$ \\
\hline White & $97(49.5)$ & $32(16,3)$ & $28(14.3)$ & $26(13.3)$ & 37 (18.9) \\
\hline Age (years) & $\mathrm{p}<0.001$ & $p=0.881$ & $\mathrm{p}=0.002$ & $p<0.001$ & $\mathrm{p}<0.001$ \\
\hline $18-39$ & $72(62.6)$ & $22(19.1)$ & $33(28.7)$ & $31(27.0)$ & $42(36.5)$ \\
\hline $40-59$ & $94(57.3)$ & $35(21.3)$ & $22(13.4)$ & $21(12.8)$ & $28(17.1)$ \\
\hline 60 or older & 9 (21.9) & $9(21.9)$ & $4(9.8)$ & $1(2.4)$ & $4(9.8)$ \\
\hline Primary School & $p=0.029$ & $p=0.043$ & $\mathrm{p}=0.732$ & $p=0.287$ & $p=0.449$ \\
\hline Not completed & $107(60.1)$ & $44(24.7)$ & $34(19.1)$ & $33(18.5)$ & $44(24.7)$ \\
\hline Completed & $68(47.9)$ & $22(15.5)$ & $25(17.6)$ & $20(14.1)$ & $30(21.1)$ \\
\hline \multicolumn{6}{|l|}{ Economic classification* } \\
\hline$A+B$ & $p=0.032$ & $p=0.059$ & $p=0.259$ & $p=0.029$ & $p=0.080$ \\
\hline C & $18(42.9)$ & $3(7.1)$ & $4(9.5)$ & $1(2.4)$ & $4(9.5)$ \\
\hline \multirow[t]{2}{*}{$\mathrm{D}$} & $76(50.3)$ & $36(23.8)$ & $31(20.5)$ & $27(17.9)$ & $37(24.5)$ \\
\hline & $78(62.9)$ & $27(21.8)$ & $24(19.3)$ & $24(19.3)$ & $32(25.8)$ \\
\hline Marital Status & $p=0.020$ & $p=0.048$ & $p=0.002$ & $p<0.001$ & $\mathrm{p}<0.001$ \\
\hline Single & $72(64.9)$ & $31(27.9)$ & $31(27.9)$ & $31(27.9)$ & $41(36.9)$ \\
\hline Married/ Has a partner & $68(51.5)$ & $20(15.1)$ & $22(16.7)$ & $17(12.9)$ & $26(19.7)$ \\
\hline Separated / divorced & $35(45.4)$ & 15 (19.5) & $6(7.8)$ & $5(6.5)$ & $7(9.1)$ \\
\hline Total & $175(54.7)$ & $66(20.6)$ & $59(18.4)$ & $53(16.6)$ & $74(23.1)$ \\
\hline
\end{tabular}


From the total sample, $18.8 \%$ of the patients were not adhering to ART and the prevalence was higher among patients who were not white $(p<0.030)$, younger $(p=0.001)$ and from lower social classes $(p=0.026)$ (Table 1). Regarding the use of psychoactive drugs, $25.8 \%$ used alcohol, $21.7 \%$ smoked and $29.7 \%$ used some illicit psychoactive substance.

The gross analysis showed that the use of any of the illicit psychoactive substances were associated to a higher probability of no adherence to ART. However, when data was adjusted by the Poisson Regression, the association between the disorders and the non-adherence to ART lost statistical significance when the sociodemographic variables were included in it, $p<0.20$, Table 2 . After the adjustment for the confounders, we observed a tendency in the association between the use of marijuana and non-adherence to ART ( $R P=1.58$; IC95\% $0.96-2.59, \mathrm{p}=0.069$ ) (Table 3).

Table 3 - Gross and adjusted prevalence ratio of the relation between the use of psychoactive substances and non-adherence to the antiretroviral therapy.

\begin{tabular}{|c|c|c|c|c|c|}
\hline \multirow{2}{*}{ Psychoactive substance } & \multicolumn{3}{|c|}{$\begin{array}{l}\text { Non-adherence to ART } \\
\text { Gross analysis }\end{array}$} & \multicolumn{2}{|c|}{$\begin{array}{l}\text { Non-adherence to ART } \\
\text { Adjusted analysis * }\end{array}$} \\
\hline & n (\%) & PR (Cl 95\%) & $\begin{array}{c}p- \\
\text { value }\end{array}$ & RP (Cl 95\%) & $\begin{array}{c}\text { p- } \\
\text { value }\end{array}$ \\
\hline Tobacco & $\begin{array}{c}38 \\
(21,7)\end{array}$ & $\begin{array}{c}1,43(0,89 \\
2,31)\end{array}$ & 0,141 & $\begin{array}{c}1,05(0,84 \\
1,32)\end{array}$ & 0,667 \\
\hline Alcohol & $\begin{array}{c}17 \\
(25,8)\end{array}$ & $\begin{array}{l}1,52(0,93 \\
\quad 2,49)\end{array}$ & 0,095 & $\begin{array}{c}1,31(0,80 \\
2,15)\end{array}$ & 0,276 \\
\hline Marijuana & $\begin{array}{c}19 \\
(32,2)\end{array}$ & $\begin{array}{c}2,05(1,29 \\
3,26)\end{array}$ & 0,003 & $\begin{array}{c}1,58(0,96 \\
2,59)\end{array}$ & 0,069 \\
\hline Crack/cocaine & $\begin{array}{c}15 \\
(28,3)\end{array}$ & $\begin{array}{c}1,68(1,01 ; \\
2,78)\end{array}$ & 0,044 & $\begin{array}{c}1,14(0,68 \\
1,91)\end{array}$ & 0,607 \\
\hline Any illicit psychoactive substance & $\begin{array}{c}22 \\
(29,7)\end{array}$ & $\begin{array}{c}1,92(1,22 \\
3,04)\end{array}$ & 0,005 & $\begin{array}{c}1,31(0,86 \\
1,99)\end{array}$ & 0,199 \\
\hline Total & $\begin{array}{c}60 \\
(18,8)\end{array}$ & --- & --- & --- & --- \\
\hline
\end{tabular}

Subtitle: Non-adherence to ART, $\mathrm{n}$ - absolute frequency; (\%) relative frequency; PR - prevalence ratio; $\mathrm{Cl}$ confidence interval. The sociodemographic variables $(p<0.20)$ were considered as possible confounders in the adjusted analysis.

Source: Data from this research (2016-2017).

The barriers for no-adhesion described by most patients were: it is difficult to remember to take the pills every day (54.5\%); having nausea (25.9\%); being away (24,5\%); being busy with other tasks $(22.5 \%)$; it is difficult to travel to take the medicine (21.0\%); and other reasons (>20\%) (Table 4).

Finally, when we analyzed the patients who used at least one psychoactive illicit substance the barriers most mentioned were: the high number of pills to be taken; the fear that other people may know they are sick; the difficulty of taking so many pills when they do not feel sick; and they do not believe in efficacy of the treatment and would rather try alternative treatments (Table 4). 
Table 4 - Prevalence of the main barriers for non-adherence to ART between the total HIV/AIDS patients sample and those who presented disorders due to the use of psychoactive substances.

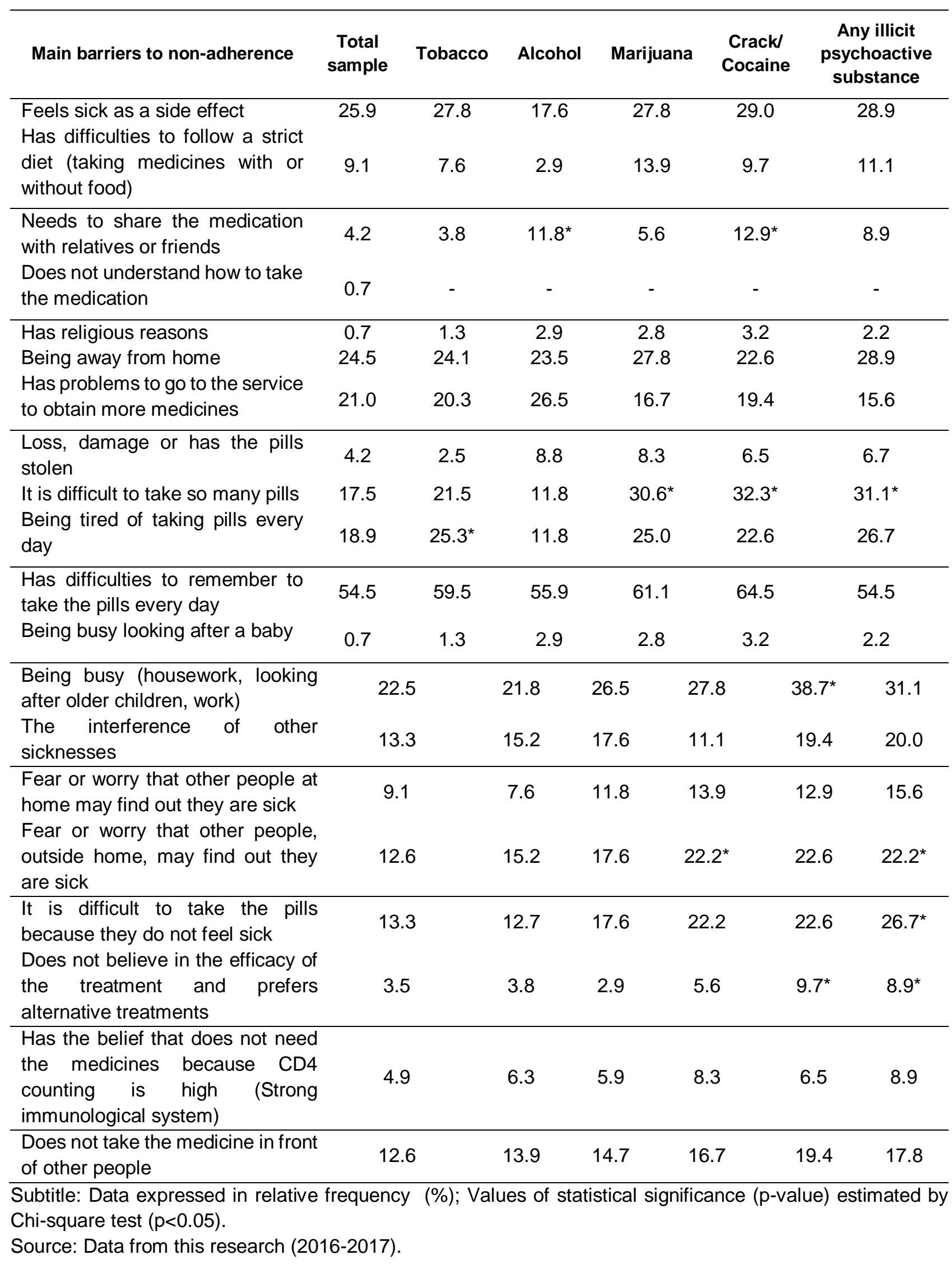




\section{DISCUSSION}

This study aimed at describing the characteristics of HIV/AIDS patients who make use of psychoactive substances and evaluating if the use of these substances is associated to the non-adherence to ART and, therefore, identifying the main barriers for no-adhesion in this population. The parameter used to identify the adherence was the detectable viral load, and it was found that $18.8 \%$ of the patients were not adhering to the antiretroviral therapy, being this prevalence similar to the ones found in other studies conducted in Brazil ( SILVA, J.A.G, 2015; NEMES, M.I.B., et al., 2009; SILVA, M.C., et al., 2009).

The no-adherence to the ART in this population was associated to the patients being of no-white skin, young (18-39 years old) and from low social classes. Hanif et al. (2013) explained that as HIV/AIDS patients in Brazil have the right to receive free treatment and care, the high prevalence of this epidemic within lower class populations may be related to the difficulty these patients have to obtain information regarding health care; their low education level; discrimination; and even the costs involved with transportation. Being young may also influence in the way these patients understand what it means to have HIV/AIDS and the importance of an early diagnostic and chronic and periodic treatment, which in the end influences in the adherence rate (HANIF, H., et al., 2013; BARCLAY, T.R., et al., 2007; GHIDEI, L., et al., 2013) and, finally, another hypothesis would be that young patients find it more difficult to change their life style and establish new routines than older patients.

Specialized literature has also suggested that the use of psychoactive substances is another clinical factor associated to non-adherence to ART. In this study, the bivariate analysis showed that the HIV/AIDS patients who were users of alcohol and tobacco had a 1.5 higher risk of non-adherence to ART. The use of alcohol and tobacco are frequently associated to non-adherence to ART (JOSEPH, B., et al., 2015; BEER, L., SKARBINSKI, J., 2014; COHN, S.E., et al., 2011; GONZALEZ-ALVAREZ, S., et al., 2017).

The use of alcohol predisposes the patients to forget to take the medication and it also worsens their perception of health (DE BONI, R.B., et al., 2016; KALICHMAN, S.C., et al., 2017). Other authors have also suggested that patients are afraid of mixing alcohol and drugs with ART (KALICHMAN, S.C., et al., 2013; KALICHMAN, S.C., et al., 2017; KALICHMAN, S.C., et al., 2015). The tobacco, on the other hand, works as a predictor of failure regarding the care with the health of the individuals, regardless its association with alcohol and other illicit substances (BEKELE, T., et al., 2017; WINHUSEN, T., et al., 2017).

Regarding the use of illicit substances, the gross analysis showed that HIV/AIDS patients who use them were twice as likely to fail to adhere to ART, and similar results were also found in studies investigating the effect of the use of illicit drugs on the adherence to ART among patients infected with HIV (MCNEIL, R., et al., 2017; COHN, S.E., et al., 2011; KALICHMAN, S.C., et al., 2015). However, after adjusting the data for the social-demographic variables, the disorders caused by the use of licit and illicit substances were no longer associated to the non-adherence to ART, which showed the great relevance of the social-economic variables.

Studies have shown that the use of psychoactive substances alone may not predispose HIV/AIDS patients to non-adherence, but if patients are also young, poor and uneducated they are then more vulnerable and more predisposed to non-adherence (ARNSTEN, J.H., et al., 2007; TORRES, T.S., et al., 2014; O'NEIL, C.R., et. al., 2012).

Furthermore, Nolan et al. found that three quarters of HIV/AIDS patients under ART, who used psichoactive substances, achieved virologic suppression, which suggests that the use of such susbtances may not be an isolated barrier to the adherence to the treatment (NOLAN, S., et al., 2017). Virologic suppression was also achieved by patients who made use of psychoactive substances when they were treated in more structured services, showing that the quality of the care may also influence in the virologic suppression (MALTA, M., et al., 2008).

One way to better understand the effect of the psychoactive substances on the adherence to HIV/AIDS treatment is to identify the barriers faced by these patients. The processes of adherence to the treatment is dynamic and modifiable and different barriers may be associated to the adherence rate and, therefore, should be constantly monitored (GONZALEZ-ALVAREZ, S., et al., 2017). When the patient fails to adhere to the 
treatment, the chances of the virus transmission increases and more resistant viral strains are developed. In a more individual level, the adherence to the ART is vital to the avoidable morbidity and mortality in HIV/AIDS patients (BRAITHWAITE, R.S., BRYANT, K.J., 2017).

In this study, HIV/AIDS patients who presented disorders caused by the use of psychoactive substances reported the following barriers in this study: i. It is tiring to take so many pills every day; ii. They need to share their treatment with relatives or friends; iii. They are afraid other people (outside home) may find out they are sick; iv. They do not believe in the efficacy of the treatment and, therefore, prefer alternative treatments; and v. They find it difficult to take the pills because they do not feel they are sick. According to Langebeek, et al. (2014), the beliefs of the HIV/AIDS patients influence the adherence to ART, and they demonstrated that individual, social and structural factors may contribute to the interruption and discontinuity of the treatment (SMALL, W., et al., 2016). Other studies have also mentioned some of the barriers presented here, such as forgetting to take the pills, being away from home and not feeling sick (COSTA, J.M., et al., 2018; LANGEBEEK, N., et al., 2014).

Some limitations should be taken into consideration when analyzing the data presented in this study. As it was a cross-sectional study, its data may be subjected to reverse causality. Moreover, the instrument used to evaluate the use of psychoactive substances does not allow us to measure the dose response effect between the increase in consumption and the self-reported scaling ruler. On the other hand, the study was conducted in a reference center for HIV/AIDS patient care, where patients are regularly treated and monitored by a group of physicians and a multidisciplinary health care team, which most probably has a positive effect over the ART adherence. Therefore the results obtained here should be applied to populations that share a similar profile.

\section{CONCLUSION}

The adherence to ART is a complex and multifaceted process that should be monitored for long periods of time. However, special attention should be given to patients who are not white and young, from lower social classes, and users of psychoactive substances, being the strategies focused on the promotion of adherence having into the consideration the barriers reported by the patients of the given communities.

\section{REFERENCE}

1. Joint United Nations Program on HIV/AIDS (UNAIDS). 2017. In: www.unaids.org/en. Acesso em: 15 mar. 2018

2. Boletim Epidemiológico. 2017. In: www.aids.gov.br. Acesso em: 15 mar. 2018.

3. JOSEPH, B., et al. Factors linked to transitions in adherence to antiretroviral therapy among HIV-infected illicit drug users in a Canadian setting. AIDS Care, 2015; 27, 1128-1136.

4. MALTA, M., et al. Adherence to antiretroviral therapy for human immunodeficiency virus/acquired immune deficiency syndrome among drug users: a systematic review. Addiction, 2008; 103, 1242-1257.

5. MCNEIL, R., et al. Antiretroviral Therapy Interruption Among HIV Postive People Who Use Drugs in a Setting with a Community-Wide HIV Treatment-as-Prevention Initiative. AIDS Behav, 2017; 21, 402-409.

6. PATERSON, D.L., et al. Adherence to protease inhibitor therapy and outcomes in patients with HIV infection. Ann Intern Med, 2000; 133, 21-30.

7. O'NEIL, C.R., et. al. Factors associated with antiretroviral medication adherence among HIV-positive adults accessing highly active antiretroviral therapy (HAART) in British Columbia, Canada. J Int Assoc Physicians AIDS Care (Chic), 2012; 11, 134141.

8. HINKIN, C.H., et al. Drug use and medication adherence among HIV-1 infected individuals. AIDS Behav, 2007; 11, 185194.

9. HENDERSHOT, C.S., et al. Alcohol use and antiretroviral adherence: review and meta-analysis. J Acquir Immune Defic Syndr, 2009; 52, 180-202.

10. LANGEBEEK, N., et al. Predictors and correlates of adherence to combination antiretroviral therapy (ART) for chronic HIV infection: a meta-analysis. BMC Med, 2014; 12, 142.

11. AZAR, M.M., et al. A systematic review of the impact of alcohol use disorders on HIV treatment outcomes, adherence to antiretroviral therapy and health care utilization. Drug Alcohol Depend, 2010; 112, 178-193.

12. KALICHMAN, S.C., et al. Intentional non-adherence to medications among HIV positive alcohol drinkers: prospective study of interactive toxicity beliefs. J Gen Intern Med, 2013; 28, 399-405. 
13. KALICHMAN, S.C., et al. Viral suppression and antiretroviral medication adherence among alcohol using HIV-positive adults. Int J Behav Med, 2014; 21, 811-820.

14. NAKIMULI-MPUNGU, E., et al. Depression, alcohol use and adherence to antiretroviral therapy in sub-Saharan Africa: a systematic review. AIDS Behav, 2012; 16, 2101-2118.

15. ARNSTEN, J.H., et al. Factors associated with antiretroviral therapy adherence and medication errors among HIV-infected injection drug users. J Acquir Immune Defic Syndr, 2007; 46, 2, S64-71.

16. O'CONNOR, J.L., et al. Factors associated with adherence amongst 5295 people receiving antiretroviral therapy as part of an international trial. J Infect Dis, 2013; 208, 40-49.

17. ROMEU, G., et al. Avaliação da adesão à terapia antirretroviral de pacientes portadores de HIV. Revista Brasileira de Farmácia Hospitalar e Serviços de Saúde 3, 2012.

18. SILVA, J.A.G. Fatores associados à não adesão aos antirretrovirais em adultos com AIDS nos seis primeiros meses da terapia em Salvador, Bahia, Brasil. .. ISSN 0102-311X. Cad. Saúde Pública [online], 2015; 31 (6), 1118-1198.

19. GONZALEZ, A., et al. Substance use: impact on adherence and HIV medical treatment. Curr HIV/AIDS Rep, 2011; 8: 4, 223-234.

20. HENRIQUE, I.F., et al. [Validation of the Brazilian version of Alcohol, Smoking and Substance Involvement Screening Test (ASSIST)]. Rev Assoc Med Bras (1992), 2004; 50, 199-206.

21. POBLETE F, et al. A randomized controlled trial of a brief intervention for alcohol and drugs linked to the Alcohol, Smoking and Substance Involvement Screening Test (ASSIST) in primary health care in Chile. Addiction, 2017; 112(8), 1462-1469.

22. CHESNEY, M.A., et al. Self-reported adherence to antiretroviral medications among participants in HIV clinical trials: the AACTG adherence instruments. Patient Care Committee \& Adherence Working Group of the Outcomes Committee of the Adult AIDS Clinical Trials Group (AACTG). AIDS Care, 2000; 12, 255-266.

23. NEMES, M.I.B., et al. Adesão ao tratamento, acesso e qualidade da assistência em Aids no Brasil. Rev. Assoc. Med. Bras, 2009; 55.

24. SILVA, M.C., et al. Risk-factors for non-adherence to antiretroviral therapy. Rev Inst Med Trop Sao Paulo, 2009; 51, 135139.

25. HANIF, H., et al. Individual and contextual factors of influence on adherence to antiretrovirals among people attending public clinics in Rio de Janeiro, Brazil. BMC Public Health, 2013; 13, 574.

26. BARCLAY, T.R., et al. Age-associated predictors of medication adherence in HIV-positive adults: health beliefs, self-efficacy, and neurocognitive status. Health Psychol, 2007; 26, 40-49.

27. GHIDEI, L., et al. Aging, antiretrovirals, and adherence: a meta analysis of adherence among older HIV-infected individuals. Drugs Aging, 2013; 30, 809-819.

28. BEER, L., SKARBINSKI, J. Adherence to antiretroviral therapy among HIV-infected adults in the United States. AIDS Educ Prev, 2014; 26, 521-537.

29. COHN, S.E., et al. Association of ongoing drug and alcohol use with non-adherence to antiretroviral therapy and higher risk of AIDS and death: results from ACTG 362. AIDS Care, 2011; 23, 775-785.

30. GONZALEZ-ALVAREZ, S., et al.. Relationship between alcohol consumption, whether linked to other substance use or not, and antiretroviral treatment adherence in HIV+ patients. Adicciones, 2017; 0, 916.

31. DE BONI, R.B., et al. Substance Use and Adherence Among People Living with HIV/AIDS Receiving cART in Latin America. AIDS Behav, 2016; 20, 2692-2699.

32. KALICHMAN, S.C., et al. Forget about forgetting: structural barriers and severe non-adherence to antiretroviral therapy. AIDS Care, 2017; 29, 418-422.

33. KALICHMAN, S.C., et al. Intentional Medication Nonadherence Because of Interactive Toxicity Beliefs Among HIV-Positive Active Drug Users. J Acquir Immune Defic Syndr, 2015; 70, 503-509.

34. BEKELE, T., et al. Trends and Correlates of Cigarette Smoking and Its Impacts on Health-Related Quality of Life Among People Living with HIV: Findings from the Ontario HIV Treatment Network Cohort Study, 2008-2014. AIDS Patient Care STDS, 2017; 31, 49-59.

35. WINHUSEN, T., et al. Baseline Cigarette Smoking Status as a Predictor of Virologic Suppression and CD4 Cell Count During One-Year Follow-Up in Substance Users with Uncontrolled HIV Infection. AIDS Behav., 2017.

36. TORRES, T.S., et al. Factors associated with tobacco smoking and cessation among HIV-infected individuals under care in Rio de Janeiro, Brazil. PLoS One, 2014; 9, e115900.

37. NOLAN, S., et al. HIV-infected individuals who use alcohol and other drugs, and virologic suppression. AIDS Care, 2017; 29, 1129-1136.

38. BRAITHWAITE, R.S., BRYANT, K.J.,. Influence of alcohol consumption on adherence to and toxicity of antiretroviral therapy and survival. Alcohol Res Health, 2010; 33, 280-287.

39. SMALL, W., et al. Plasma HIV-1 RNA viral load rebound among people who inject drugs receiving antiretroviral therapy (ART) in a Canadian setting: an ethno-epidemiological study. AIDS Res Ther, 2016; 13, 26.

40. COSTA, J.M., et al. Adherence to antiretroviral therapy for HIV/AIDS in Latin America and the Caribbean: Systematic review and meta-analysis. J Int AIDS Soc, 2018; 21. 